\title{
Occurrence of genus Scenedesmus Mayen (Chlorophyceae) from East Nepal
}

\author{
Shiva Kumar Rai \\ Department of Botany \\ Post Graduate Campus, Tribhuvan University, Biratnagar, Nepal \\ E-mail: shivarai24244@yahoo.com
}

\begin{abstract}
s
A total 18 taxa of genus Scenedesmus (Chlorococcalean algae) has been reported from the freshwater habitats of east Nepal. Among them, 5 taxa viz., Scenedesmus abundans, S. arcuatus var. platydiscus, S. disciformis, S. hystrix, and S. perforatus are new records for Nepal. A total 12 taxa viz., $S$. acuminatus, S. acutus, S. armatus var. asymmetricus, S. bernardii, S. bijuga, S. bijugatus var. graevenitzii, S. dimorphus, S. opoliensis, S. prismaticus, $S$. quadricauda var. longispina, S. quadricauda var. westii and S. smithii are first time reported from east Nepal.
\end{abstract}

Key words: Green algae, chlorococcales, Acutodesmus, Comasiella, Desmodesmus, taxonomy, new to Nepal.

\section{Introduction}

Scenedesmus Mayen is a chlorococcalian freshwater green algae. It is single celled or colonial with 2, (usually 4 or 8 ), 16 to 32 celled coenobia. In colonial form, cells are arranged linearly in one row ( 4 celled) or alternately in 2 to 3 rows ( 8 or more celled), attaching with lateral walls or in sub-polar region only. Each cell is spherical to ellipsoidal, elongate or fusiform in shape; 3-78 $\mu \mathrm{m}$ long, 2-10 $\mu \mathrm{m}$ broad; apices capitate, obtuse, acute or tapering; cell wall ribed, granulated or dented without spines. Nucleus single; chloroplast single, parietal with single pyrenoid. Reproduce asexually by not-motile autospores; sexual reproduction is rare, only reported in S. obliquus.

Scenedesmus is planktonic in eutrophic freshwater ponds and lakes distributed world-wide in all climates. It tolerates slight acidity but only low salinity and appropriate temperature for its growth is $28-30^{\circ} \mathrm{C}$. Scenedesmus is used as a biological tool for physiological experimens and pollution problems. In sewage treatment, it provides oxygen to the bacteria for the breakdown of organic matters. Scendesmus obliquus and S. obtusus are produced in mass culture and used as food because they contain rich protein and minerals. Recently, after Botriococcus, it is one of the important algae using for the production of biofuel.

There are more than 461 species of Scenedesmus recorded throughout the World, of which 74 are currently accepted taxonomically (Guiry \& Guiry, 2013). The genus Scenedesmus was named by Meyen (1829). Scenedesmus of Nepal has been studied by Hirano (1955, 1963), Hickel (1973a, b), Nakanishi (1986), Nakano and Watanabe (1988), Sahay et al. (1992), Chaturvedi and Habib (1996), Das and Verma (1996) and Rai (2009) and altogether 46 species of Scenedesmus have been reported from the country till the time. Most of the species were reported from Kaski (Phewa, Rupa, Begnas, Khaste Lakes), Kathmandu (Rani Pokhari, Taudaha, Boudha), Lalitpur (Godawari), Chitwan (Narayangar), Nawalparasi (Gaindakot), Kanchanpur (Mahendranagar), Makawanpur (Hetauda fish pond, Kara river), Gorkha (Arughat, Ankhu 
Khola, Luitel Bhanjyang), and Mustang (Tukucha Moor, Pisang) districts. The present communication described total taxa of geneus Scenedesmus from east Nepal.

\section{Materials and Methods}

Algae samples were collected from lotic and lentic habitats of eastern Nepal with the help of plankton mesh net and by squeezing submerged parts of aquatic macrophytes and preserved in $4 \%$ formalin solution. Glycerine-mount temporary slides of fresh material were prepared and observed by LM Leica under 40X magnification. Photomicrography was taken with the help of Canon digital camera and identification was done following Prescott (1951), Philipose (1967), Hegewald and Silva (1988), John and Tsarenko (2002), and Guiry and Guiry (2013). Dimension of coenobia and cells, number and pattern of arrangement of cells in a colony, spines etc are considered as criterion for identification.

\section{Taxonomic Description}

Systematic position of Scenedesmus according to Guiry and Guiry (2013) is as follows:

Empire: $\quad$ Eukaryota

Kingdom: $\quad$ Plantae

Phylum: Chlorophyta

Class: $\quad$ Chlorophyceae

Order: $\quad$ Sphaeropleales

Family: Scenedesmaceae

Subfamily: Scenedesmoidea

Genus: $\quad$ Scenedesmus Meyen 1829.

Kessler et al. (1997) has classified Scenedesmus into two subgenera i.e., Scenedesmus for nonspiny forms and Desmodesmus for spiny forms, on the basis of 16S rRNA gene sequence, DNA base composition, and DNA/DNA hybridization analysis. Later on, An et al. (1999) has confirmed a distinct separation between them by analyzing ITS-2 rDNA sequence and get separated into two distinct genera.

The lectotype of Scenedesmus is Scenedesmus obtusus Meyen. They are described as follows.

1. Scenedesmus abundans (Kirchner) Chodat (Figs. 22, 32, 33) (Basionym: Scenedesmus caudatus f. abundans Kirchner; Heterotype: Scenedesmus sempervirens Chodat)

Current accepted name Desmodesmus abundans (Kirchner) E. Hegewald

Characters: Colonies 2 to 4 celled, rarely 8 celled, arranged in a linear series; cells ovoid to oblong-ovoid, external cells with one or more median lateral spines from the outer face in addition to spines from the four corners of the colony, internal cells with 1-2 spines from their poles, or rarely without spines.

Dimension: Cells 6-15 $\mu \mathrm{m}$ long, 2-7 $\mu \mathrm{m}$ broad; spines 3.5-8 $\mu \mathrm{m}$ long.

Locality and Date: A pond at Koshi Tappu Wildlife Reserve, 81 m, Sunsari, Nepal (2065/8/11).

Distribution in Nepal: New to Nepal.

Distribution in the World: New South Wales, Queensland (Day et al., 1995), Britain (John \& Tsarenko, 2002), Iran (Afsharzadeh et al., 2003), China (Cao et al., 2005), Singapore (Pham et al., 2011), Romania (Caraus, 2012). 
2. Scenedesmus acuminatus (Lagerheim) Chodat (Figs. 23-25, 27, 28) (Basionym: Selenastrum acuminatum Lagerheim; Homotype: Selenastrum acuminatum Lagerheim; Heterotypes: Scenedesmus acuminatus var. elongatus G.M. Smith, S. obliquus var. acuminatus (Lagerheim) Chodat, S. falcatus Chodat, S. bernardii G.M. Smith, S. acuminatus var. minor G.M. Smith, S. falcatus f. tortuosa Skuja, S. acuminatus f. tortuosus (Skuja) Korshikov)

Current accepted name: Acutodesmus acuminatus (Lagerheim) Tsarenko

Characters: Colonies curved, usually 4 celled, sometimes 8 celled; cells fusiform, lunate with sharp pointed ends; external cells usually sharply lunate, internal cells sometimes flat; rarely, all cells in the same plane; cell wall smooth, without teeth or spines.

Dimension: Cell 12-45 $\mu \mathrm{m}$ long (between apices), 2-7 $\mu \mathrm{m}$ broad.

Locality and Date: Shallow marshy land at Koshi Tappu Wildlife Reserve, 80 m, Sunsari, Nepal (2065/9/18).

Distribution in Nepal: Rupa and Khaste Lakes, 900 m, Kaski (Hickel, 1973a); Fish pond near Mahendranagar road, Kanchanpur (Chaturvedi \& habib, 1996).

Distribution in the World: Victoria (Day et al., 1995), Britain (John \& Tsarenko, 2002), Cuba, New South Wales, Pakistan (Mehwish \& Aliya, 2005), Canary Islands, China (Hu \& Wei, 2006), Turkey (Ersanli \& Gönülol, 2006), Brazil (Menezes, 2010), Spain (Pérez et al., 2010), Singapore (Pham et al., 2011), Portugal, Queensland, Romania (Caraus, 2012).

3. Scenedesmus acutiformis Schröder (Figs. 1, 16, 17, 20)

Current accepted name: Enallax acutiformis (B. Schröder) F. Hindák

Characters: Colonies flat, usually 4 celled, sometimes 2 to 8 celled; cells arranged in a linear series, each cell fusiform, cylindrical with acute apices and a lateral longitudinal ridge; poles without teeth or spines; cell wall smooth.

Dimension: Cells 17.5-21.5 $\mu \mathrm{m}$ long, 6-6.5 $\mu \mathrm{m}$ broad.

Locality and Date: A shallow marshy land, 80 m, Koshi Tappu Wildlife Reserve, Sunsari, Nepal $(2065 / 9 / 18)$.

Distribution in Nepal: Pond near Godawari fish farm, 1500 m, Lalitpur (Nakano \& Watanabe, 1988); Karra river at Hetauda, 500 m, Makawanpur (Sahay et al., 1992); Mai Pokhari lake, 2150 m, Ilam (Rai, 2009)

Distribution in the World: Spain, Victoria (Day et al., 1995), Britain (John \& Tsarenko, 2002), New South Wales, Pakistan (Mehwish \& Aliya, 2005), China (Hu \& Wei, 2006), Romania (Caraus, 2012)

4. Scenedesmus acutus Meyen (Fig. 26) (Heterotypes: Scenedesmus dimorphus f. granulates Isabella \& R.J. Patel, Arthrodesmus acutus Ehrenberg ex Ralfs, Scenedesmus crassus Chodat, Scenedesmus scenedesmoides Chodat)

Current accepted name: Scenedesmus obliquus (Turpin) Kützing 
Characters: Colonies usually 4 celled, sometimes 2 to 8 celled, mostly with clearly alternating cells, rarely solitary cells or forming one serial row; cells spindle, internal cells straight, external ones clearly arcuate; young ones concave, older ones slightly convex but with curved ends; poles sometimes finger-like extended; cell wall smooth.

Dimension: Cells 10.4-24 $\mu \mathrm{m}$ long, 3-7.2 $\mu \mathrm{m}$ broad.

Locality and Date: A shallow marshy land at Koshi Tappu Wildlife Reserve, 80 m, Sunsari, Nepal (2065/9/18).

Distribution in Nepal: A pond at Ankhu Khola, 640 m, Gorkha (Hirano, 1955).

Distribution in the World: Denmark (Ettl \& Gärtner, 1995), New South Wales (Day et al., 1995), Spain (Aboal, 1996), China (Cao et al., 2005), Argentina (Rodriguez et al., 2006), Brazil (Menezes, 2010), Queensland, Romania (Caraus, 2012).

\section{Scenedesmus arcuatus Lemm. var. platydiscus G.M. Smith (Fig. 4)}

Current accepted name: Comasiella arcuata var. platydisca (G.M. Smith) E. Hegewald et M. Wolf

Characters: Colonies flat, 8 celled, arranged in double rows; cells oblong-ellipsoidal with rounded ends, cells between two rows distinctly alternate; without teeth or spines; cell wall smooth.

Dimension: Cells 8-14 $\mu \mathrm{m}$ long, 4-5.5 $\mu \mathrm{m}$ broad.

Locality and Date: Titrigachi pond and a shallow marshy land, 80 m, Koshi Tappu Wildlife Reserve, Sunsari, Nepal (2065/9/18).

Distribution in Nepal: New to Nepal.

Distribution in the World: Queensland (Day et al., 1995), Balearic Islands (Cambra Sánchez et al., 1998), Britain (Whitton et al., 2003), Turkey (Soylu \& Gönülol, 2006), Spain (Fanés Treviño et al., 2009), Brazil (Menezes, 2010).

6. Scenedesmus armatus (Chodat) G.M. Smith var. asymmetricus Philip. (Fig. 21)

Current accepted name: Desmodesmus armatus (R. Chodat) E. Hegewald var. asymmetricus Philip.

Characters: Colonies 4 - 8 celled, arranged in one row; a fairly long oblique spine from one pole of the terminal cell and a short more or less erect spine from the other pole, the long and short spines of the two terminal cells alternating with each other, one half of the internal cells with a short spine from one pole and the other half with a similar spine from the opposite pole, the short spines of the terminal and internal cells of each half of the colony standing in a row.

Dimension: Cells 11-12.3 $\mu \mathrm{m}$ long, 3.5-4.4 $\mu \mathrm{m}$ broad; short spines 3-3.5 $\mu \mathrm{m}$ long, long spines 5.8-6.2 $\mu \mathrm{m}$ long.

Locality and Date: A shallow marshy land, 80 m, Koshi Tappu Wildlife Reserve, Sunsari, Nepal (2065/9/18). 
Distribution in Nepal: Pond near Sarada Dam, Mahendranagar (Chaturvedi \& Habib, 1996).

Distribution in the World: Kerala, India (Philipose, 1967).

7. Scenedesmus bernardii G.M. Smith (Fig. 12)

Current accepted name: Acutodesmus bernardii (G.M. Smith) E. hegewald, C. Bock et Krienitz

Characters: Colonies 4 to 8 celled; internal cells fusiform, lunate or sigmoid with acute apices and arranged alternately with their apices in contact with the apices or median portions of adjacent cells; terminal cells fusiform or lunate, usually attached to the apices of the inner cell and frequently at an angle to the plane of the colony; cell without teeth and spines; cell wall smooth.

Dimension: Cells 8-25 $\mu \mathrm{m}$ long, 3-5.5 $\mu \mathrm{m}$ broad.

Locality and Date: An artificial pond near human settlement area, 81 m, Koshi Tappu Wildlife Reserve, Sunsari (2065/08/11).

Distribution in Nepal: A pond near Arughat, $770 \mathrm{~m}$, Gorkha (Hirano, 1963); Fish pond at Hetauda, Makawanpur (Sahay et al., 1992).

Distribution in the World: Australia and New Zealand (Day et al., 1995), Britain (Whitton et al., 2003), Romania (Caraus, 2012).

8. Scenedesmus bijuga Turpin (Lagerheim) (Figs. 29-31) (Basionym: Achnanthes bijuga Turpin)

Characters: Colonies 2, 4, or 8 celled, flat, arranged in one linear row; cells oblong to ovoid with broadly rounded ends, external cells broader than the internal ones with convex outer margin, internal cells narrower with broadly rounded ends; without teeth and spines.

Dimension: Cells 9-15 $\mu \mathrm{m}$ long, 3-5 $\mu \mathrm{m}$ broad.

Locality and Date: An artificial pond near human settlement area, $81 \mathrm{~m}$, Koshi Tappu Wildlife Reserve, Sunsari (2065/08/11).

Distribution in Nepal: Rupa and Begnas lakes, 900 m, Kaski (Nakanishi, 1986).

Distribution in the World: Spain (Alvarez Cobelas \& Gallardo, 1986), Arkansas, North America (Smith, 2010), Singapore (Pham et al., 2011).

9. Scenedesmus bijugatus (Turp.) Kütz. var. graevenitzii (Bernard) Chodat (Figs. 5, 19, 40, 41)

Characters: Colonies 4 to 8 celled; cells fusiform, ellipsoid, oblong-ellipsoid to ovoid with obtuse apices, cells arranged in alternate series with adjacent cells in contact only along a short portion of their length; without teeth and spines.

Dimension: Cells 11-16 $\mu \mathrm{m}$ long, 4.5-6.5 $\mu \mathrm{m}$ broad.

Locality and Date: Locality and Date: Triyuga river, 152 m, Gaighat, Udayapur (2003/05/25); A shallow marshy land, 80 m, Koshi Tappu Wildlife Reserve, Sunsari, Nepal (2065/9/18). 
Distribution in Nepal: Lamaha river (Sahay et al., 1992).

Distribution in the World: North America (Prescott, 1951), India (Philipose, 1967).

10. Scenedesmus dimorphus (Turp.) Kütz. (Fig. 34) (Basionym: Achnanthes dimorpha Turpin; Homotype: Scenedesmus obliquus var. dimorphus (Turpin) Hansgirg, S. acutus var. dimorphus (Turpin) Rabenhorst, Achnanthes dimorpha Turpin; Heterotype: Scenedesmus antennatus Brébisson, S. costulatus Chodat, S. acutus var. obliquus Rabenhorst)

Current accepted name: Acutodesmus dimorphus (Turpin) Tsarenko

Characters: Colonies 4 to 8 celled; cells arranged in a linear or sub-alternating series (in 8 celled colony); cells fusiform, external cells more or less lunate or curved, internal cells straight and more or less hexagonal in shape; cell apices sharp and acute, without teeth and spines.

Dimension: Cells 17-20 $\mu \mathrm{m}$ long, 3-5 $\mu \mathrm{m}$ broad.

Locality and Date: Birat Pokhari, 135 m, Anarmani, Jhapa (2004/06/17); A shallow marshy land, 80 m, Koshi Tappu Wildlife Reserve, Sunsari, Nepal (2065/9/18).

Distribution in Nepal: A pond at Bauddha, 1300 m, Kathmandu (Hirano, 1963); Fish pond at Hetauda, Makawanpur (Sahay et al., 1992).

Distribution in the World: Northern Territory, Queensland and Victoria (Day et al., 1995), Britain (Whitton et al., 2003), Spain, Pakistan (Leghari et al., 2005), China (Hu \& Wei, 2006), Turkey (Ersanli \& Gönülol, 2006), Iran (Ramzannejad Ghadi, 2008), Arkansas (Smith, 2010), Brazil (Menezes, 2010), New Zealand (Broady et al., 2012), Queensland, Romania (Caraus, 2012).

11. Scenedesmus disciformis (Chodat) Fott et Komárek (Fig. 11) (Basionym: Scenedesmus bijugatus var. disciformis Chodat)

Current accepted name: Scenedesmus verrucosus Y.V. Roll

Characters: Colonies 2, 4, usually 8 celled; cells arrange in two rows, each joined together without distinct openings; each cell cylindrical with rounded tops slightly arcuated, on the margin with concave or convex outer sides; cell wall smooth.

Dimension: Cells 17-20 $\mu \mathrm{m}$ long, 8-9.5 $\mu \mathrm{m}$ broad.

Locality and Date: MMAM Campus pond, 72 m, Biratnagar, Morang (2004/02/02); A shallow pond, 80 m, Koshi Tappu Wildlife Reserve, Sunsari, Nepal (2065//11).

Distribution in Nepal: New to Nepal.

Distribution in the World: Spain (Aboal, 1996); Romania (Caraus, 2012).

12. Scenedesmus hystrix Lagerheim (Figs. 3, 8, 9, 18)

Current accepted name: Desmodesmus hystrix (Lagerheim) E.H. Hegewald

Characters: Colonies 2, 4, 8 celled; cells arranged in one linear series; each cell oblongcylindrical with obtuse ends; cell membrane covered with minute spines. 

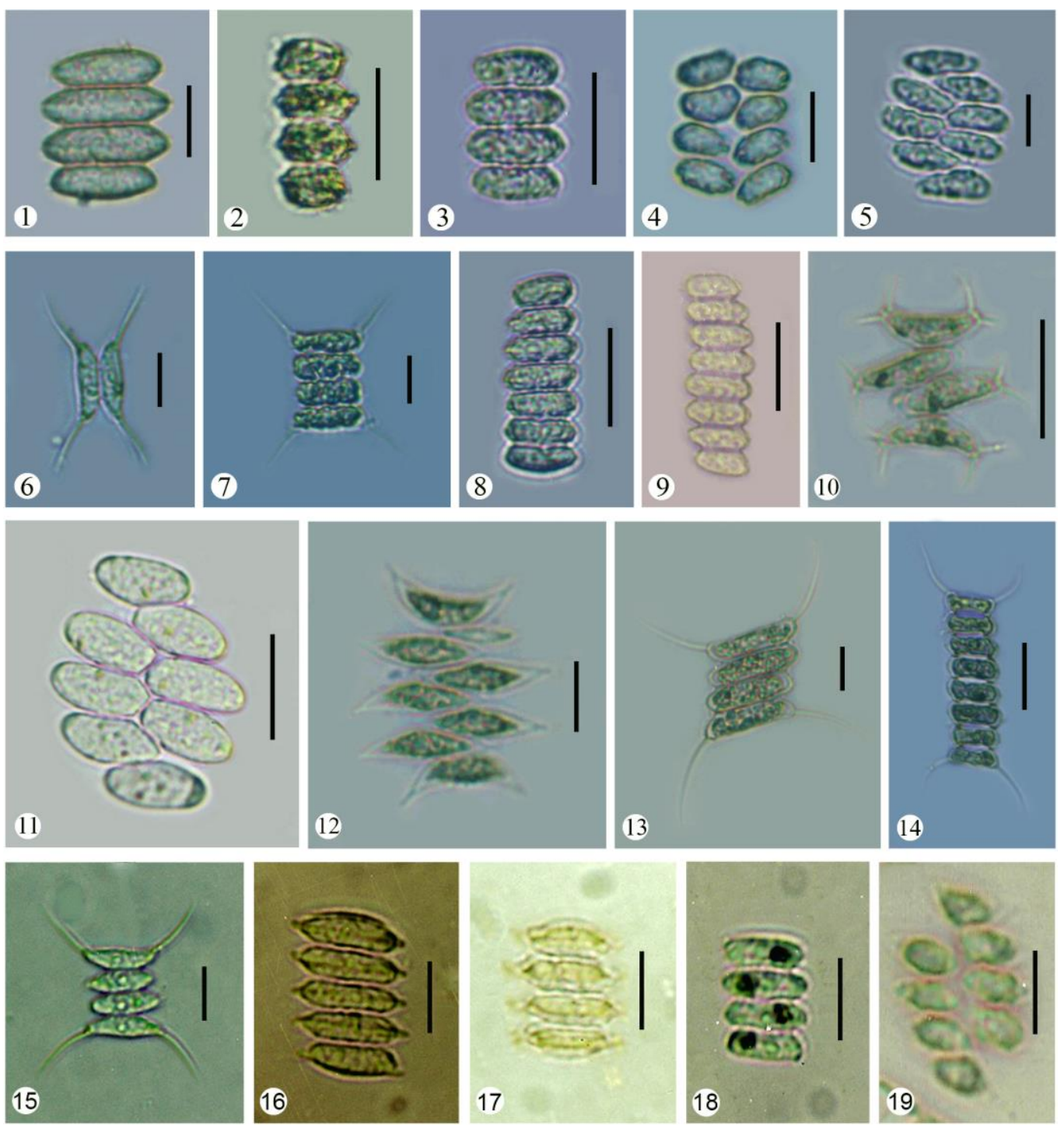

Figures: 1, 16, 17. Scenedesmus acutiformis; 2. S. prismaticus; 3, 8, 9, 18. S. hystrix; 4. S. arcuatus var. platydiscus; 5, 19. S. bijugatus var. gravenitzii; 6, 15. S. opoliensis; 7. S. quadricauda var. longispina; 10. S. smithii; 11. S. disciformis; 12. S. bernardii; 13. S. quadricauda var. westii; 14. S. perforatus $($ Scale bar $=10 \mu \mathrm{m})$

Dimension: Cells 13-19 $\mu \mathrm{m}$ long, 4-7 $\mu \mathrm{m}$ broad.

Locality and Date: Triyuga river, 152 m, Gaighat, Udayapur (2003/05/25).

Distribution in Nepal: New to Nepal.

Distribution in the World: Queensland (Day et al., 1995), Spain (Cambra Sánchez et al., 1998), Andorra, Balearic Islands, Britain (John \& Tsarenko, 2002), Pakistan (Mehwish \& Aliya, 2005), Romania (Caraus, 2012). 
13. Scenedesmus opoliensis P.G. Richter (Figs. 6, 15, 35-39) (Heterotype: Scenedesmus carinatus f. brevicaudatus Uherkovich; Scenedesmus opoliensis var. setosus Dedusenko)

Current accepted name: Desmodesmus opoliensis (P.G. Richter) E. Hegewald

Characters: Colonies 2, 4 celled; cells cylindrical to subfusiform, arranged in a linear series; adjacent cells in contact only along one third of their length; internal cells tumid in the median region and attenuated towards the ends; terminal cells often narrower and sub-rectangular; poles of all cells semitruncate to rostrate, sometimes ending in one or two very short spines; terminal cells with long, more or less recurved spine.

Dimension: Cells 13-15 $\mu \mathrm{m}$ long, 4.2-4.5 $\mu \mathrm{m}$ broad; spines 11-12.5 $\mu \mathrm{m}$ long.

Locality and Date: Hattisar Campus pond, 511 m, Dharan, Sunsari (2004/05/28).

Distribution in Nepal: Rupa lake and Khaste lake, 900 m, Kaski (Hickel, 1973a); A pond at Custom Office, Mahendranagar, Kanchanpur (Chaturvedi \& Habib, 1996).

Distribution in the World: New South Wales and Victoria (Day et al., 1995), Portugal and Spain (Cambra Sanchez et al., 1998), Britain (Whitton et al., 2003), China (Hu \& Wei, 2006), Turkey (Ersanli \& Gönülol, 2006), Arkansas (Smith, 2010), Singapore (Pham et al., 2011), Romania (Caraus, 2012).

\section{Scenedesmus perforatus Lemm. (Fig. 14)}

Current accepted name: Desmodesmus perforatus (Lemmermann) E. Hegewald

Characters: Colonies usually 8 celled, sometimes 4 celled; cells with capitates ends; outer face of external cells slightly convex, inner face concave; poles curved outwards and with a long recurved spine; internal cells with concave sides and with linear to lenticular perforations between adjacent cells; cell membrane smooth or punctuate.

Dimension: Cells $16.5 \mu \mathrm{m}$ long, $5-5.5 \mu \mathrm{m}$ broad; spines $18 \mu \mathrm{m}$ long; opening between the cells $1.4 \mu \mathrm{m}$.

Locality and Date: Mechi Pokhari, 80 m, Mahespur, Bhadrapur, Jhapa (2004/06/17).

Distribution in Nepal: New to Nepal.

Distribution in the World: Australia and New Zealand (Day et al., 1995), Pakistan (Mehwish \& Aliya, 2005), China (Hu \& Wei, 2006), Turkey (Ersanli \& Gönülol, 2006).

\section{Scenedesmus prismaticus Bruehl et Biswas (Fig. 2)}

Characters: Colonies 4 celled; cells arranged in a single linear series; cells prismatic with pyramidal end faces, meeting at sharp angles; each cell with a median longitudinal ridge, prominent at the poles.

Dimension: Cells 12-15 $\mu \mathrm{m}$ long, $7.5 \mu \mathrm{m}$ broad.

Locality and Date: Titrigachi pond, 81 m, Koshi Tappu, Kusaha, Sunsari (2003/03/29). 

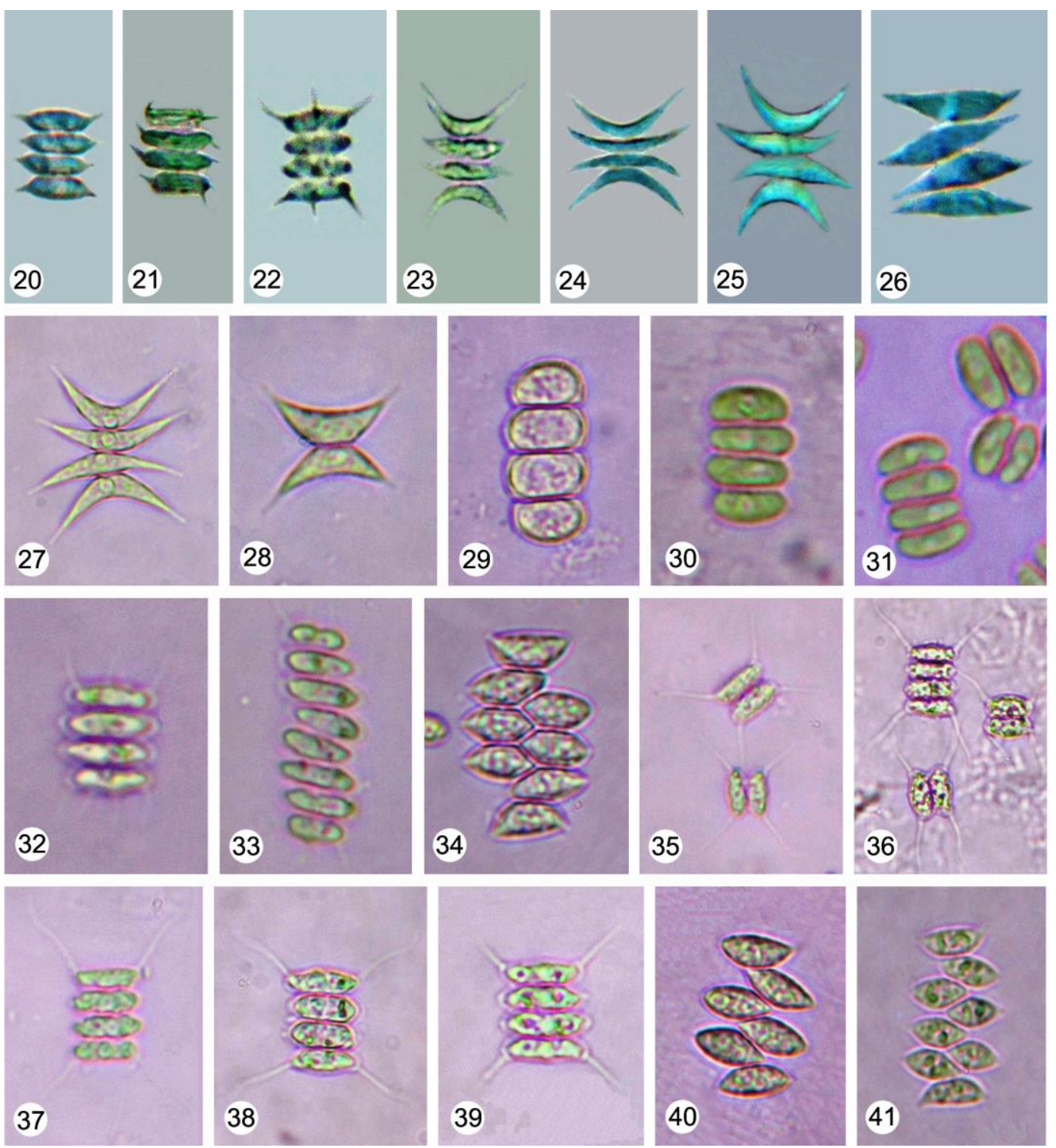

Figures: 20. Scenedesmus acutiformis; 21. S. armatus var. asymmetricus; 22, 32, 33. S. abundans; 23-25, 27-28. S. acuminatus; 26. S. acutus; 29-31. S. bijugatus; 34. S. dimorphus; 35-39. S. opoliensis; 40-41. S. bijugatus var. gravenitzii.

Distribution in Nepal: Karra river at Hetauda, 500 m, Makawanpur (Sahay et al., 1992); A pond near Mahendranagar Bazar, Kanchanpur (Chaturvedi \& Habib, 1996).

Distribution in the World: India and Malaysia (Ettl \& Gartner, 1995).

16. Scenedesmus quadricauda (Turp.) Bréb. var. longispina (Chodat) G.M. Smith (Fig. 7) (Basionym: Scenedesmus longispina R. Chodat)

Current accepted name: Scenedesmus longispina R. Chodat 
Characters: Colonies usually 2-4 celled; cells ovoid to cylindrical, spines slightly longer than the length of the cells, internal cells without spines, sometimes with very short delicate spines from some of their poles; cell wall smooth.

Dimension: Cells $15 \mu \mathrm{m}$ long, $5 \mu \mathrm{m}$ broad; spines 13-15 $\mu \mathrm{m}$ long.

Locality and Date: Mechi Campus pond, 93 m, Bhadrapur, Jhapa (2004/06/17).

Distribution in Nepal: Fish pond and Karra river, Hetauda, Makawanpur (Sahay et al., 1992); A pond near Nepal forest at Mahendranagar, Kanchanpur (Chaturvedi \& Habib, 1996).

Distribution in the World: Arkansas, North America (Smith, 2010)

17. Scenedesmus quadricauda (Turp.) Bréb. var. westii G.M. Smith (Fig. 13)

Current accepted name: Scenedesmus maximus (West \& G.S. West) Chodat

Characters: Colonies usually 4 to 8 celled; cells ovoid to cylindrical, arranged obliquely, larger than var. longispina, spines slightly curved; cell wall smooth.

Dimension: Cells $21 \mu \mathrm{m}$ long, $5.6 \mu \mathrm{m}$ broad; spines $20-25 \mu \mathrm{m}$ long.

Locality and Date: Birat Pokhari, 135 m, Anarmani, Jhapa (2004/06/17).

Distribution in Nepal: Fish pond, Hetauda, Makawanpur (Sahay et al., 1992).

Distribution in the World: As Scenedesmus maximus, Spain (Cambra Sánchez et al., 1998), As $S$. westii, Arkansas, North America (Smith, 2010)

18. Scenedesmus smithii Teil. (Fig. 10)

Characters: Colony 4 celled; cells arranged in a sub-alternating series, more or less naviculoid with the sides of cells, where they are in contact with one another, flat; 2 to 3 sharp spines from the pole of each cell, spines sometimes oblique.

Dimension: Cells $19 \mu \mathrm{m}$ long, 5-6 $\mu \mathrm{m}$ broad; spines $5 \mu \mathrm{m}$ long.

Locality and Date: Pond at Botany Dept, MMAM Campus, $72 \mathrm{~m}$, Biratnagar, Morang (2004/02/02); Birat Pokhari, 135 m, Anarmani, Jhapa (2004/06/17).

Distribution in Nepal: A pond near Indo-Nepal road, Mahendranagar, Kanchanpur (Chaturvedi \& Habib, 1996).

Distribution in the World: Romania (Caraus, 2012).

\section{Conclusion}

The present work described a total 18 taxa of genus Scenedesmus collected from freshwater lotic and lentic habitats of east Nepal. Out of them, five taxa viz., Scenedesmus abundans, S. arcuatus var. platydiscus, S. disciformis, S. hystrix, and S. perforatus are new records for Nepal. Similarly, total 12 taxa viz., S. acuminatus, S. acutus, S. armatus var. asymmetricus, S. bernardii, S. bijuga, S. bijugatus var. graevenitzii, S. dimorphus, S. opoliensis, S. prismaticus, S. quadricauda var. longispina, S. quadricauda var. westii and S. smithii are new to study area (east Nepal). 


\section{Acknowledgement}

Author is thankful to the head, Prof. Dr. Sasinath Jha, Department of Botany, PG Campus, Biratnagar for laboratory facility.

\section{References}

Aboal, M. 1996. Epipelic algal communities in irrigation chanels of Southeastern Spain. Arch. Hydrobiol. Algological Studies 82: 117-131.

Afsharzadeh, S., T. Nejadsatari, M.R. Rahiminejad \& M. Ebrahimnejad. 2003. Study of algal flora in Zayanderood river. Iranian Journal of Biology 14: 32-45.

Alvárez Cobelas, M. \& T. Gallardo. 1986. Catálogo de las algas continentales españolas. IV.Chlorophyceae Wille in Warming 1884. Prasinophyceae T. Christensen ex Silva 1980. Acta Bot. Malacitana 11: 17-38.

An, S.S., T. Friedl, \& E. Hegewald. 1999. Phylogenetic relationships of Scenedesmus and Scenedesmus-like coccoid green algae as inferred from ITS-2 rDNA sequence comparisons. Plant Biology 1: 418-428. http://dx.doi.org/10.1111/j.1438-8677.1999.tb00724.x

Broady, P.A., E.A. Flint, W.A. Nelson, V. Cassie Coope, M.D. De Winton \& P.M. Novis. 2012. Phylum Chlorophyta and Charophyta: green algae. In: New Zealand inventory of biodiversity. Volume 3. Kingdoms Bacteria, Protozoa, Chromista, Plantae, Fungi. (Gordon, D.P. Eds), pp. 347-381. Christchurch: Canterbury University Press.

Cambra Sánchez, J., M. Álvarez Cobelas \& M. Aboal Sanjurjo. 1998. Lista florística y bibliográfica de los clorófitos (Chlorophyta) de la Península Ibérica, Islas Baleares e Islas Canarias. pp. 1614. Burgos: Asociación Española de Limnología.

Cao, X., A. Strojsová, P. Znachor \& E. Zapomelová. 2005. Detection of extracellular phosphatases in natural spring phytoplankton of a shallow eutrophic lake (Donghu, China). European Journal of Phycology 40: 251-258. http://dx.doi.org/10.1080/09670260500192760

Caraus, I. 2012. Algae of Romania. A distributional checklist of actual algae. Version 2.3 third revision. Bacau: Univ. Bacau.

Chaturvedi, U.K. \& I. Habib. 1996. A systematic account of Chlorococcales from Nepal. Phykos 35(1-2): 129-137.

Das, S.N. \& B.N. Verma. 1996. Algal flroa of Chitwan and Nawalparasi districts of Nepal. Phykos 35(1-2): 119-127.

Day, S.A., R.P. Wickham, T.J. Entwisle \& P.A. Tyler. 1995. Bibliographic check-list of non-marine algae in Australia. Flora of Australia Supplementary Series 4: 1-276.

Ersanli, E. \& A. Gönülol. 2006. A study on the phytoplankton of Lake Simenit, Turkey. Cryptogamie Algologie 27: 289-305.

Ettl, H. \& G. Gärtner. 1995. Syllabus der Boden-, Luft- und Flechtenalgen. pp. 1-721. Stuttgart: Gustav Fischer.

Fanés Treviño, I., A. Comas González \& P.M. Sánchez Castillo. 2009. Catálogo de las algas verdes cocales de las aguas continentales de Andalucía. Acta Botanica Malacitana 34: 1-22.

Guiry, M.D. in M.D. Guiry \& G.M. Guiry. 2013. AlgaeBase. World-wide electronic publication, National University of Ireland, Galway. http://www.algaebase.org; searched on 1 March 2013.

Hegewald, E. \& P.C. Silva. 1988. Annotated catalogue of Scenedesmus and nomenclaturally related genera, including original descriptions and figures. Bibliotheca Phycologica. 80. Cramer, Stuttgart, 587 p., 900 plates.

Hickel, B. 1973a. Limnological investigations in lakes of Pokhara valley, Nepal. Int. Rev. ges Hydrobiol. 58(5): 659-672.

Hickel, B. 1973b. Phytoplanktons in two ponds in Kathmandu valley, Nepal. Int. Rev. ges Hydrobiol. 58(6): 835-842. 
Hirano, M. 1955. Fresh water algae. In: Fauna and flora of Nepal Himalaya (Kihara, H. Ed.), Fauna and Flora Research Society, Kyoto University, Kyoto, Japan. pp. 5-42.

Hirano, M. 1963. Fresh water algae from the Nepal Himalaya, collected by a member of the Japanese Climbing Expedition. Contr. Biol. Lab., Kyoto Univ., Japan. 16: 1-23.

Hu, H. \& Y. Wei. 2006. The freshwater algae of China. Systematics, taxonomy and ecology. pp. [4 pls of 16 figs], [i-iv], i-xv, 1-1023. China: www.sciencep.com.

John, D.M. \& P.M. Tsarenko. 2002. Order Chlorococcales. In: The Freshwater Algal Flora of the British Isles. An identification guide to freshwater and terrestrial algae. (John, D.M., B.A. Whitton \& A.J. Brook Eds.), pp. 327-409. Cambridge: Cambridge University Press.

Kessler, E., M. Schäfer, C. Hümmer, A. Kloboucek \& V.A.R. Huss. 1997. Physiological, biochemical, and molecular characters for the taxonomy of the subgenera of Scenedesmus (Chlorococcales, Chlorophyta). Botanie Acta 110: 244-250. http://dx.doi.org/10.1111/j.1438-8677.1997. tb00636.X

Leghari, S.M., M.Y. Khuhawar, T.M. Jahangir \& A. Leghari. 2005. Limnological study of Pir Bukhari (Karsaz) and Manghopir warm springs, Karachi, Sindh, Pakistan. Int. J. Phycol. Phycochem. 1(2): 151-158.

Mehwish, H. \& R. Aliya. 2005. Occurrence of freshwater algae at different localities of Karachi University. Int. J. Phycol. Phycochem. 1(2): 117-124.

Menezes, M. 2010. Chlorophyceae. In: Catálogo de plantas e fungos do Brasil. Vol. 1. (Forzza, R.C. Eds), pp. 335-352. Rio de Janeiro: Andrea Jakobsson Estúdio; Instituto de Pesquisas Jardim Botânico do Rio de Janeiro.

Nakanishi, M. 1986. Limnological study in Phewa, Begnas and Rupa lakes. In: Studies on distribution, adaptation and evolution of microorganisms in Nepal Himalayas (Second report), (Ishida, Y. Ed.), Ministry of Education, Science and Culture, Kyoto, Japan. Pp. 3-13.

Nakano, T. \& M. Watanabe. 1988. Some species of Chlorococcales from Nepal. In: Cryptogams of the Himalayas, Vol. 1, The Kathmandu valley, (Watanabe, M. \& S.B. Malla Eds), National Science Museum, Tsukuba, Japan. pp. 57-65.

Pérez, M.C, A. Comas \& N. Maidana. 2010. Estudio taxonómico del fitoplancton del tramo inferior del río Júcar con especial énfasis en las algas verdes cocales (Valencia - España). ALGAS. Boletín de la Sociedad Española de Ficología 44: 13-19, 7 Fig., 1 Table.

Pham, M.N., H.T.W. Tan, S. Mitrovic \& H.H.T. Yeo. 2011. A checklist of the algae of Singapore. pp. 1-100. Singpore: Raffles Museum of Biodiversity Research, National University of Singapore.

Philipose, M.T. 1967. Chlorococcales, I.C.A.R. monograph on algae, New Delhi. 365p.

Prescott, G.W. 1951. Algae of the western great lakes area. WM.C. Brown Publishers, Dubuque, Iowa. 977p.

Rai, S.K. 2009. Some chlorophycean algae from Maipokhari Lake, Ilam, east Nepal. J. Nat. Hist. Mus, Nepal 24: 1-8.

Ramzannejad Ghadi, R. 2008. Epipelic algae of Miankaleh International Wetland (North of Iran).

Rodriguez, P.L., H. Pizarro, N. Maidana, Afonso Dos Santos \& S.M. Bonaventura. 2006. Epixylic algae from a polluted lowland river of Buenos Aires province (Argentina). Cryptogamie Algologie 27: 63-83.

Sahay, A.P., P.K. Das \& B.N. Verma. 1992. Studies on the algal flora of Nepal-I: Chlorophyceae. Geophytology 20(2): 155-158.

Smith, T.E. 2010. Revised list of algae from Arkansas, U.S.A. and new additions. International Journal on Algae 12(3): 230-256. http://dx.doi.org/10.1615/InterJAlgae.v12.i3.30

Soylu, E.N. \& A. Gönülol. 2006. Seasonal variation in the diversity, species richness and composition of the phytoplankton assemblages in a shallow lake. Cryptogamie Algologie 27: 85-101.

Whitton, B.A., D.M. John, M.G. Kelly \& E.Y. Haworth. 2003. A coded list of freshwater algae of the British Isles. Second Edition. World-wide Web electronic publication. 